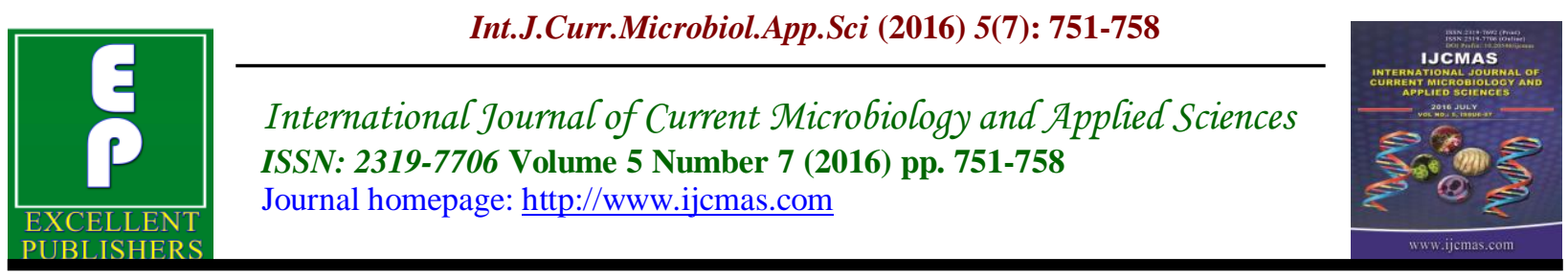

Original Research Article

http://dx.doi.org/10.20546/ijcmas.2016.507.086

\title{
Extraction of Chitin and Chitosan from Biowaste of Scampi Macrobrichum rosenbergii and Tiger Shrimp Penaeus monodon
}

\author{
V. Panchakshari, K. Srikanth, P.V. Krishna* and Ch. Suresh Babu \\ Department of Zoology and Aquaculture, Acharya Nagarjuna University \\ Nagarjuna Nagar-522 510, Andhra Pradesh, India \\ *Corresponding author
}

\begin{tabular}{|c|c|}
\hline & A B S T R A C T \\
\hline Keywords & \multirow{5}{*}{$\begin{array}{l}\text { Chitin and chitosan is an important natural resources and are estimated that } \\
\text { almost as much as cellulose. Chitin is the fiber in shellfish such as crab, } \\
\text { cobster, shrimp, and prawn. The shrimp industry generates a huge amount of } \\
\text { shell waste per processing which usually cause environmental nuisance. This } \\
\text { waste can be utilized as an economic source of chitin and its derivative } \\
\text { chitosan. The chitin and chitosan are considered versatile and promising } \\
\text { biomaterial. Keeping the significance of chitin and chitosan, the present } \\
\text { investigation has taken up to evaluate the yield percentage and quality } \\
\text { parameters between the fresh water prawn Macrobrachium rosenberfii and } \\
\text { tiger shrimp Penaeus monodon. Compare with the between two species } M \text {. } \\
\text { rosebergii was better chitosan producer. }\end{array}$} \\
\hline $\begin{array}{l}\text { Chitin, } \\
\text { Chitosan, } \\
\text { M.rosenberii } \\
\text { and } \\
\text { P.monodon. }\end{array}$ & \\
\hline Article Info & \\
\hline $\begin{array}{l}\text { Accepted: } \\
\text { 22 June } 2016\end{array}$ & \\
\hline $\begin{array}{l}\text { Available Online: } \\
10 \text { July } 2016\end{array}$ & \\
\hline
\end{tabular}

\section{Introduction}

Nanoparticles are becoming increasingly important in many areas, including catalysis, biological applications and information storage. Their unique size-dependent properties make these materials superior Chitin and chitosan are the second most available biopolymer after cellulose. Chitosan extraction consists of four common steps such as demineralization, deproteinisation, decolourisation and $\mathrm{N}$ deacetylation. Synthetic polymers have all along been the major materials involving in our daily life. They are seen in a wide range of applications from dietary to mechanical support. However, they have also created problems in disposal as they are considered not biodegradable and take up millions years to degrade back to the nature. In other words, they consume a large space and become a major issue as environmental pollution increasing the demands for biopolymers, which exhibit the characteristic of biocompatibility, biodegradable, and non-toxicity. Chitosan being as a biopolymer extracted from shrimp shells can be developed to act as a solution for environmental issue. In addition, chitosan also gains its fame in wastewater treatment and bio medical field due to its metal absorption and antibacterial properties respectively. Derivatives of chitin oligomers have also been implicated as morphogenic factors in the communication between 
leguminous plants and Rhizobium and even in vertebrates, where they may be important during early stages of embryogenesis (Bakkers et al., 1999). In India alone 60,000 to 80,000 tonnes of chitinous wastes are produced annually, from which a lot of chitin can be recovered from crustacean biowaste (Suresh and Chandrasekaran, 1998). At present only a small quantity of shell waste is utilized for animal feed or chitin isolation (Synowiecki and AlKhateeb, 2003).

Conventionally these wastes are disposed off either by burning or land filling better use methods are harmful to the environment, since burning releases carbon dioxide and carbon monoxide to the environment, which adds to global warming while land filling is harmful due to slow rate of degradation and concomitant release of a potent pollutant of ground water, namely, ammonia (Muzzarelli, 1997). The cost of transporting such as waste, environmental pollution concern and ethical questions as to the morality of ignoring $70-80 \%$ of the dry weight of the catch have highlighted the necessity of finding alternative method (Simpson and Haard, 1985; Vyas and Deshpande, 1991). Utilization of such chitinous wastes for the production of some useful products is being considered lately, and two different approaches are being investigated: The formation of a useful product such as chitin and chitosan through biological (Gagne and Simpson, 1993) and their uses in sewage treatment, animal feed, food preservation, and formulations of biofungicides (Muzzarelli, 1997; Gohel et al., 2005), Using the waste as a carbon source in fermentation processes for the production of useful products such as chitinolytic enzymes by microorganisms.. Recently the commercial value of chitin has increased because of the beneficial properties of its soluble derivatives, which are suitable in chemistry, biotechnology, agriculture, food processing, cosmetics, veterinary, medicine, dentistry, environment protection and paper or textile production (Synowiecki and Al-Khateeb, 2003; Tharanathan and Kittur, 2003). Generation of this enormous amount of waste and more importantly the increasing commercial value of the soluble derivatives of chitin necessitates the development of a suitable process for solubilization of chitinous waste and its conversion into useful polymers. The chemical methods by which these polymers and their oligomers are produced commercially involve treatment with harsh chemicals like hydrochloric acid and sodium hydroxide. Besides being environmentally unsafe, the use of these chemicals leads to products that lack uniformity. The enzymatic methods, which employ enzymes such as chitinases, are mild and eco-friendly, and thus preferred over chemical methods.

Chitosan made from chitin is a white to light-red solid powder, insoluble in water, soluble in organic acids, but indigestible by human digestive enzymes. It does not dissolve in standard polar and non polar solvents. Chitosan is insoluble in most organic solvents and in water at neutral $\mathrm{pH}$. However, it dissolves in acidic solutions. Chitin and its derivative chitosan are of commercial interest due to their excellent biocompatibility, biodegradability, nontoxicity, chelating and adsorption power. With these characteristics especially chitosan has many attractive applications in biotechnology, food and pharmaceutical industry, in cosmetics, environmental engineering, in agriculture and aquaculture (Muzzarelli et al., 2012; Franco and Peter 2011; Ling et al. 2011). Quality of chitosan is determined from several parameters, the degree of deacetylation is a quality parameter that indicates an acetyl group which can be removed from yield of 
chitosan. High deacetylation degree of chitosan means that the acetyl group contained in the chitosan is weak. Deacetylation degree of chitosan varies between 56-99\% an average of $80 \%$ depending on the source and method of preparation (Hussain et al., 2013). Other quality parameters of chotosan are the colour of a chitosan, wherein the application of chitin and chitosan also dependent on its colour. Chitosan with white colour or looks clean has better quality so commonly used in the field of health and food industries.

Keeping in view of significance and applications of chitosan, the present investigation has been taken up to evaluate the difference in yield $\%$ and in the quality parameters between the fresh water prawn Macrobrachium rosenbergii and marine shrimp Penaeus monodon.

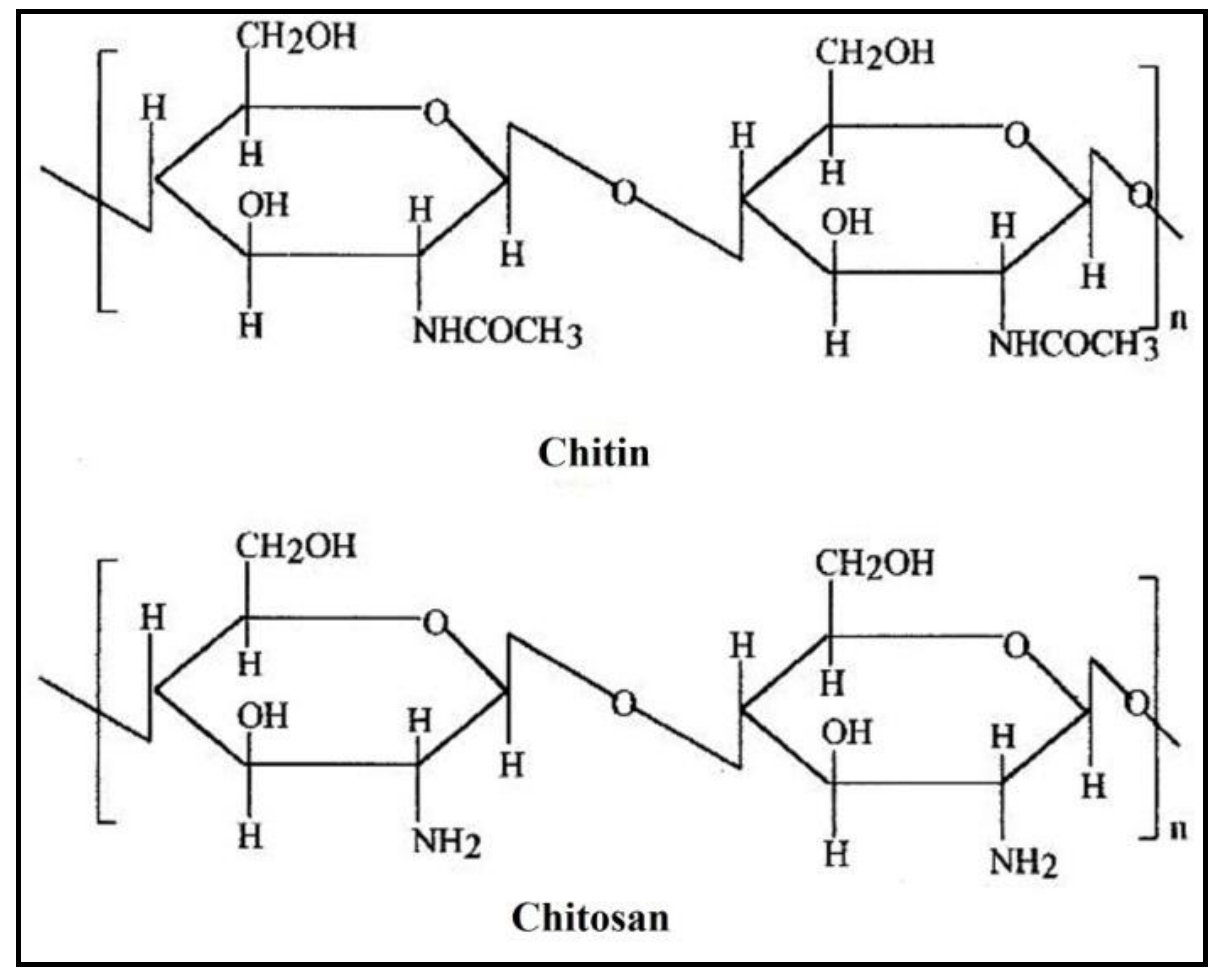

\section{Materials and Methods}

One $\mathrm{Kg}$ of freshwater prawn Macrobrachium rosenbergii and marine shrimp Penaeus monodon collected from culture ponds at Bhimavaram. Bo-waste (carapace, exoskeleton, appendages, etc) are separated from the both samples, and wet weight of both samples was noted. Shell material now allowed to dry at $50^{\circ} \mathrm{C}$ in oven for $24 \mathrm{~h}$ and homogenized in a laboratory mixer before shipping for further processing. The yield of both dried shell samples were determined by weighing after being dried. The obtained shell samples were stored at about $25^{\circ} \mathrm{C}$ in the storage facility till needed. The most common procedure is chemically very simple, treatment of biowaste with $4 \%$ alkali to separate the protein and treatment with $4 \%$ acid to remove the calcium carbonate. The resulting chitin products can also be further deacetylated by concentrated $50 \%$ alkali to produce chitosan.

Crushed biowaste samples were placed in $1000 \mathrm{ml}$ beakers and soaked in boiling 
sodium hydroxide ( 2 and $4 \% \mathrm{w} / \mathrm{v}$ ) for one hour at $70-120^{\circ} \mathrm{C}$ in order to dissolve the proteins and sugars thus isolating crude chitin. $4 \% \mathrm{NaOH}$ is used for chitin preparation, concentration used by the scientists at the Sonat corporation. After the samples are boiled in the sodium hydroxide, the beakers containing the shell samples are removed from the hot pate, and allowed to cool for 30 minutes at room temperature. The exoskeletons are then further crushed to pieces of $0.5-5.0 \mathrm{~mm}$ using a meat tenderizer. The grounded exoskeleton samples are de-mineralized using $1 \% \mathrm{HCl}$ with four times its quantity. The samples are allowed to soak for $24 \mathrm{~h}$. to remove the mineral (mainly calcium carbonate). The demineralized samples were then treated for one hour with $50 \mathrm{ml}$ of a $2 \% \mathrm{NaOH}$ solution to decompose the albumen into water soluble amino-acids. The remaining chitin is washed with deionized water, which is then drained off. The chitin was further, converted in to chitosan by the process of deacetylation

The deacetylation process is carried out by adding $50 \% \mathrm{NaOH}$ and then boiled at $100^{\circ} \mathrm{C}$ for $2 \mathrm{~h}$ on a hot plate. The samples are placed under the hood and cooled for 30 min. at room temperature. After wards the samples are washed continuously with the $50 \% \mathrm{NaOH}$ and filtered in order to retain the solid matter, which is the chitosan. The samples were then left uncovered and oven dried at $110^{\circ} \mathrm{C}$ for $6 \mathrm{~h}$. the chitosan obtained will be in a creamy white form (Muzzarelli and Rochetti, 1985).

\section{Characterization of Prepared Chitosan}

\section{Degree of Deacetylation}

Degree of deacetylation refers to the removal of acetyl group from the chain, this is determined by potentiometric titration.
Chitosan homogenous solution is prepared using dil. $\mathrm{HCl}$ containing $0.010 \mathrm{~mol} / \mathrm{L}$ which is titrated against $0.1 \mathrm{M} \mathrm{NaOH}$. The end point is detected by the inflection of the $\mathrm{pH}$ values. Two inflections were mainly noted out of which first one corresponds to neutralization of $\mathrm{HCl}$ and second one to the neutralization of ammonium ions for chitosan chain. The difference between two points give the amount of the amino group in the chtosan chain (degree of deacetylation) (Zhanga et al., 2010).

\section{Ash Value}

To determine the ash value of chitosan, $2.0 \mathrm{~g}$ of chitosan sample is placed into previously ignited, cooled, and tared crucible. The samples are heated in a muffle furnace preheated to $6500 \mathrm{C}$ for $4 \mathrm{~h}$. the crucibles are allowed to cool in the furnace to less than 2000C and then placed inti desiccators with a vented top. Percentage of ash value is calculated using the following.

$\%$ Ash $=\frac{\text { Weight of Residue }(\mathrm{g})}{\text { Sample Weight }(\mathrm{g})} \times 100$

\section{Moisture Content}

Crude chitin sample was placed in a preweighted aluminium dish. The dish and contents were then placed in an oven at 1050C for $24 \mathrm{~h}$. The aluminum dish along with the dried sample was first placed in a desiccator to cool down and then weighted. The moisture content was determined as follows (Mahmoud, 2007)

Moisture Content $=\frac{W w s-W d s}{W w s} \times 100$

$\mathrm{MC}=$ Moisture content $(\%)$

Wws $=$ Weight of the wet sample $(\mathrm{g})$

$\mathrm{Wds}=$ Weight of the dry sample $(\mathrm{g})$ 


\section{Proteins}

Protein was estimated according to the method described by Lowery et al., (1951). One gram of cultured copepod, P.parvus was homogenized with double distilled water and the extract was centrifuged at $4000 \mathrm{rpm}$ for 10 minutes. To $1 \mathrm{ml}$ of the supernatant, $4 \mathrm{ml}$ of Biuret reagent was added and incubated for 20 minutes. The optical density (OD) of the color developed was read at 540nm using spectrophotometer and the protein was calculated by referring to the standard graph of Bovine serum Albumin. The result was expressed in percentage.

\section{Fats}

For the estimation of fats, chloroform: methanol method was followed (Folch et al., 1957). Sample (400 mg) was homogenized with $5 \mathrm{ml}$ of chloroform: methanol mixture (2:1) and filtered by a fat filtering unit. The filtered solution was poured into a previously weighed $10 \mathrm{ml}$ beaker and kept in an oven at $70^{\circ} \mathrm{C}$ for $24 \mathrm{hrs}$. The difference in weight between the empty beaker and the beaker containing fat was expressed as the amount of fat in the sample analyzed.

\section{Percentage of Yield}

Percentage of yield for chitosan was calculated from the weight of chitosan produced as a percentage of starting dry raw material (Zaku et al., 2011).

$\%$ Chitin or Chitosan $=\frac{\text { Weight of Residue }(\mathrm{g})}{\text { Weight of initial dry raw materia (g) }} \times 100$

\section{Results and Discussion}

The results of the present study given in Table No.1 and 2. Chitin and chitosan are attracting a great deal because of their distinctive biological and physico-chemical characteristics. Chitin and chitosan have been used in various industries ranging from waste management to aqua food processing, medicine and Biotechnology. To date a lot of research been done to produce chitin and chitosan from various sources like shrimp (Laila et al., 2010; Kucukgulmez et al., 2012; Tajik et al., 2008); Crab (Felecity et al., 2007; Matheis et al., 2012) and other sources like insects and moluscus.

Table.1 Yield of bio-waste from two experimental organisms

\begin{tabular}{|l|c|c|c|c|}
\hline $\begin{array}{c}\text { Experimental } \\
\text { Species }\end{array}$ & $\begin{array}{c}\text { Total sample } \\
\text { weight } \mathbf{( g )}\end{array}$ & $\begin{array}{c}\text { Wet Bio-waste } \\
\text { (g) }\end{array}$ & $\begin{array}{c}\text { Dry weight of } \\
\text { crude (g) }\end{array}$ & $\begin{array}{c}\text { Chitosan yield per } \\
\text { Kg of sample (g) }\end{array}$ \\
\hline $\begin{array}{l}\text { Macrobrachium } \\
\text { rosenbergii }\end{array}$ & 1000 & 580 & 124.8 & 32.44 \\
\hline Penaeus monodon & 1000 & 455 & 109.2 & 26.64 \\
\hline
\end{tabular}

Table.2 Proximate analysis of exoskeleton Macrobrachium rosenbergii and Penaeus monodon

\begin{tabular}{|l|c|c|}
\hline \multicolumn{1}{|c|}{ Parameter } & Macrobrachium rosenbergii & Penaeus monodon \\
\hline Moisture (\%) & $75.2 \pm 5.6$ & $76.2 \pm 5.7$ \\
\hline Ash Content $(\%)$ & $33.25 \pm 3.38$ & $34.9 \pm 3.87$ \\
\hline Proteins $(\%)$ & $31.25 \pm 2.38$ & $28.89 \pm 2.17$ \\
\hline Fats $(\%)$ & $4.77 \pm 0.15$ & $6.77 \pm 0.95$ \\
\hline
\end{tabular}


The fresh water prawn Macrobrachium rosenbergii and shrimp Peneaus monodon are one of the potential species for chitosan production. In the present study biowaste of $580 \mathrm{mg}$ M.rosenbergii goes to $32.44 \mathrm{gms}$ chitosan, P.monodon produced 455 gms biowaste and this biowaste produced 26.64gms of chitosin.

Extraction of chitosan from freshwater prawn Macrobrachium rosenbergii and tiger shrimp Penaeus monodon exoskeleton requires chemical treatment the shell even though contains majority of chitin, also has proteins and minerals. The chitin and chitosan are used in the preparation of materials like wound dressing, antiviral and antifungal agents, dialysis membranes Biomedical beads, Fabrics and gauzes (Subashinghe, 1999). Chitosan is a wound healing accelerator, and its effectiveness in protecting wound from bacterial invasion by suppressing bacterial proliferation. It may cat as effectively against typhoid producing microorganism (Yadav and Bhine, 2004). The result of present study one $\mathrm{kg}$ of prawn Macrobrachium rosenbergii sample produced $580 \mathrm{gms}$ of biowaste and Penaeus monodon produced $455 \mathrm{gms}$ of biowaste. In case of yield goes to $124.8 \mathrm{gms}$ ( $M$. rosenbergii) and $109.2 \mathrm{gms}(P$. monodon) in the sample (Table. 1).

It has been observed that the percentage of chitosan yield from shrimp waste collected from Penaeus semisulcatus is found to be $32.25 \%$ (Khanafari et al., 2008), chitosan yield from biowaste of Penaeus carinatus and Penaeus monodon was found to be $34 \%$ (Yateendra et al., 2012),it is reported as 18.6\% (Alimuniar et al., 1992), 30\% (Sibi et al., 2013), 17\% (Mohanasrinivasan, 2014), chitosan yield from biowaste of Penaeus monodon, chitosan yield from the biowaste of Penaeus monodon was found to be $67.47 \%$ and 46\% (Anshar patria, 2013;
Divya et al., 2014). It is obvious that the amount of chitosan yield is proportional to the amount chitin obtained from the biowaste of shellfish, the amount of chitin yield intern depend on the amount of biowaste obtained from shellfish. Partially acetylated chitosan polymers exhibit a number of biological activities, including antimicrobial activities, elicitor activities inducing disease resistance in plants, and diverse stimulating or inhibiting activities towards a number of normal or transformed human cell types. Purified and well characterized chitosan showed biological activities correlated with physico-chemical properties of the polymers used. The source made from waste (chitosan) shows an excellent antimicrobial activity against human pathogens. Thus, it can be used as good potent source against the infectious pathogens.

\section{References}

Alimuniar, A., Zainuddin, R. 1992. An economical technique for producing chitosan. In: Brine CJ, Sanford PA, Zikakis JP (eds) Advances in chitin and chitosan. Elsevier Applied Science, Landon and New York, pp. 627-632.

Anshar Patria. 2013. Production and characterization of chitosan from shrimp shell waste, Aquaculture, Aquarium, Conservation \& Legislation Int. J. Bioflus Soc., 6(4): 120-125.

Bakkers, J., S.J. Bellworthy, H.P. Reader, et al. 1999. Effect of ezzymes during viniofication on colour and sensory properties of port wines. American J. Enol. Viticulture, 50: 271-276.

Divya, K., Rebello, S., Jisha, M.S. 2014. A simple and effective method for extraction of high purity chitosan from shrimp shell waste, proceedings of the conf. on advances in applied sciences and environmental engineering Chemistry, 90: 809-814.

Felicity, B., Clifford, L., Michael, A., Oghenekome, O. 2007. Extraction and 
Evaluation of Chitosan from Crab Exoskeleton as a Seed Fungicide and Plant Growth Enhancer, AmericanEurasian J. Agric. \& Environ. Sci., 2(2): 103-111.

Folch, J.M., M. Lees and G.H. Sloane-Stanley, 1957. A simple method for thye isolation and purification of total lipids from animal tissues. J. Biol. Chem., 226: 497-509.

Franco, T.T., Peter, M.G. 2011. Advances in chitin and chitosan research. Polym Int., 60: 873-874.

Gagne, Simpson, B.K. 1993. Use of proteolytic enzyme to facilitate the recovery of chitin revocery from shrimp wastes. Food Biotechnol., 7: 253-263.

Gohel, V., Chaudhari, T., Vyas, P., Chhatpar, H.S. 2004. Isolation and Identification of marine chitinolytic bacteria and their potential in antifungal biocontrol. Indian J. Exp. Biol., 42: 715-720.

Hussain, M.R., Iman, M., Maji, T.K. 2013. Determination of degree of deacetylation of chitosan and their effect on the release behavior of essential oil from chitosan and chitosan-gelatin complex microcapsules, Int. J. Adv. Engi. Appli., Vol.6, pp. 4-12.

Khanafari, A., Marandi, R., Sanatei, Sh., 2008. Recovery of chitin and chitosan from shrimp waste by chemical and microbial methods, Iran. J. Environ. Health. Sci. Eng., Vol. 5, No.1, pp. 19-24.

Kucukgulmez, A., O. Gulnaz, M. Celik, Y. Yanar, A.E. Kadak \& G. Gercek. 2012. Antimicrobial Activity of the Chitosan Extracted from Metapenaeus stebbingi Shell Wastes. J. Polym. Environ., 20: 431-437.

Laila, M., Olfa, G.B., Kemel, J., Islem, Y. \& Moncef, N. 2010. Extraction and Characterization of Chitin, Chitosan, and Protein Hydrolysates Prepared from Shrimp Waste by Treatment with Crude Protease from Bacillus cereus SV1, Appl. Biochem. Biotechnol., 162: 345357.

Ling, S.F., Yee, C.Y., Eng, H.S. 2011.
Removal of a cationic dye using deacylated chitin (chitosan). J. Appl. Sci., 11: 1445-1448.

Lowery, O.H., N.J. Rosenberg, A.L. Fare and R.J. Randall, 1951. Protein measurement with the Follin-Phenol reagent. J. Bio. Chem., 193: 265-275.

Mahmoud, N.S., Ghaly, A.E., Arab, F. 2007. Unconventional approach for demineralization of deprotenized crustacean shells for chitin production. Americal L. Biochem. Biotechnol., 3(1): 1-9.

Matheis, F.J.D.P. Tanasale, Amos, K., \& Marsela, S.L. 2012. Kitosan dari Limbah Kulit Kepiting Rajungan (Portunus sanginolentus L.) sebagai Adsorben Zat Warna Biru Metilena, Jurnal Natur Indonesia, 14(2): 165-171.

Mohanasrinivasan, V., Mudit Mishra, Jeny Singh, P., Suneet, Kr., Singh, Selvarajan, E., Suganthi, V., Subathra Devi, C. 2014. Studies on heavy metal removal efficiency and antibacterial activity of chitosan prepared from shrimp shell waste, Springer, 4: 167175.

Muzzarelli, R.A.A., Rochetti, T. 1985. Determination of the degree of deacetylation of chitosan by first derivative ultraviolet spectrophotometry. J. Carbohydr. Polym., 5: 461-72.

Muzzarelli, R.A.A. 1977. Chitin. Pergamon Press. New York, pp 97.

Sibi, G., Dhananjaya, K., Ravikumar, K.R., Mallesh, H., Venkatesh, R.T., Dwijendra, T., Prasad Bhusal, K., Neeraj, Krishne, G. 2013. Preparation of glucosamine hydrochloride from crustacean shell waste and its quantitation by RP-HPLC, AmericanEurasian J. Scientific Res., 8(2): 63-67.

Simpson, B.K., Haard, N.F. 1995. The use of proteolytic enzymes to extract carotenoproteins from shrimp wastes. $J$. Appl. Biochem., 71: 212-222.

Subasinghe, S. 1999.Chitin from shellfish waste health benefits over -shadowing 
industrial areas. Infofish Int., 3/99:5865.

Suresh, P.V., Chandrasekaran, M. 1998. Utilization of prawn waste for chitinase production by the marine fungus Beauveria bassiana by solid state fermentation, World J. Microb. Biotechnol., 14: 655-660.

Synowiecki, J., Al-Khateeb, N.A. 2003. Production, properties, and some new applications of chitin and its derivatives. Crit. Rev. Food Sci. Nutri., vol. 43, no. 2, p. 145-171.

Tajik, H., Mehran, M.M., Seyed, M.R.R., Amir, MM.F., Farnood, S.S.J. 2008. Preparation of Chitosan from Brine Shrimp (Artemia urmiana) Cyst Shells and Effects of Different Chemical Processing Sequences on the Physicochemical and Functional Properties of the Product, Mol., 13: 1263-1274.

Tajik, H., Mehran, M.M., Seyed, M.R.R., Amir, MM.F. \& Farnood, S.S.J. 2008. Preparation of Chitosan from Brine Shrimp (Artemia urmiana) Cyst Shells and Effects of Different Chemical Processing Sequences on the Physicochemical and Functional Properties of the Product, Mol., 13: 1263-1274.

Tharanathan, R.N. and Kittur, FS. 2003. Chitin--the undisputed biomolecule of great potential. Crit. Rev. Food Sci. Nutr., 43(1): 61-87.

Tsai, G.J., Su, W.H., Chen, H.C., \& Pan,
C.L. 2002. Antimicrobial Activity of Shrimp Chitin and Chitosan from different Treatments and Applications of Fish Preservation, Fisheries Sci., 68: 170-177.

Vyas, P.R. and Deshpande, M.V. 1991. Enzymatic hydrolysis of chitin by Myrothecium verrucaria chitinase complex and its utilization to produce SCP. J. General and Appl. Microbiol., vol. 37, no. 3, p. 267-275.

Yadav, A.V. and S.B. Bhise. 2004. Chitosan: A potential biomaterial effective against typhoid. Curr. Sci., Vol.87, No.9: 11761178.

Yateendra, P.S., Saikishore, V., Sudeshanababu, S. 2012. Extraction of chitin from chitosan from exoskeleton of shrimp for application in the pharmaceutical industry, Int. Curr. Pharma. J., 1(9): 258-263.

Zaku, S.G., Emmanuel, S.A., Aguzue, O.C., Thomas, S.A. 2011. Extraction and characterization of chitin; a functional biopolymer obtained from scales of common carp fish (Cyprinus carpio1): A lesser known source, African J. Food Sci., Vol.5 (8), pp. 478-483.

Zhang, Q.H.G., M.A., Mai, K.S. 2010. Intreaction of dietary Bacillus sibtilius and fructooligosaccharide on the growth performance non-specific immunity of sea cucumber, Apostichopus japonicas, Fish Shell Fish Immunol., 29: 204-211.

\section{How to cite this article:}

Panchakshari, V., K. Srikanth, P.V. Krishna and Ch. Suresh Babu. 2016. Extraction of Chitin and Chitosan from Biowaste of Scampi Macrobrichum rosenbergii and Tiger Shrimp Penaeus monodon. Int.J.Curr.Microbiol.App.Sci. 5(7): 751-758.

doi: http://dx.doi.org/10.20546/ijcmas.2016.507.086 